\title{
Front Matter: Volume 8762
}

"Front Matter: Volume 8762," Proc. SPIE 8762, PIAGENG 2013: Intelligent Information, Control, and Communication Technology for Agricultural Engineering, 876201 (19 March 2013); doi: 10.1117/12.2025108

SDIE Event: Third International Conference on Photonics and Image in Agriculture SPIE. Engineering (PIAGENG 2013), 2013, Sanya, China 


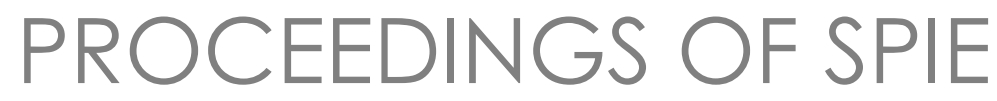

\title{
PIAGENG 2013: Intelligent Information, Control, and Communication Technology for Agricultural Engineering
}

\author{
Honghua Tan \\ Editor
}

27-28 January 2013

Sanya, China

Organized and Sponsored by

Wuhan University of Technology (China)

Information Engineering Research Institute (United States)

Published by

SPIE 
The papers included in this volume were part of the technical conference cited on the cover and title page. Papers were selected and subject to review by the editors and conference program committee. Some conference presentations may not be available for publication. The papers published in these proceedings reflect the work and thoughts of the authors and are published herein as submitted. The publisher is not responsible for the validity of the information or for any outcomes resulting from reliance thereon.

Please use the following format to cite material from this book:

Author(s), "Title of Paper," in PIAGENG 2013: Intelligent Information, Control, and Communication Technology for Agricultural Engineering, edited by Honghua Tan, Proceedings of SPIE Vol. 8762 (SPIE, Bellingham, WA, 2013) Article CID Number.

ISSN: 0277-786X

ISBN: 9780819495594

Published by

SPIE

P.O. Box 10, Bellingham, Washington 98227-0010 USA

Telephone +1 3606763290 (Pacific Time) · Fax +1 3606471445

SPIE.org

Copyright (@ 2013, Society of Photo-Optical Instrumentation Engineers.

Copying of material in this book for internal or personal use, or for the internal or personal use of specific clients, beyond the fair use provisions granted by the U.S. Copyright Law is authorized by SPIE subject to payment of copying fees. The Transactional Reporting Service base fee for this volume is $\$ 18.00$ per article (or portion thereof), which should be paid directly to the Copyright Clearance Center (CCC), 222 Rosewood Drive, Danvers, MA 01923. Payment may also be made electronically through CCC Online at copyright.com. Other copying for republication, resale, advertising or promotion, or any form of systematic or multiple reproduction of any material in this book is prohibited except with permission in writing from the publisher. The CCC fee code is 0277-786X/13/\$18.00.

Printed in the United States of America.

Publication of record for individual papers is online in the SPIE Digital Library.

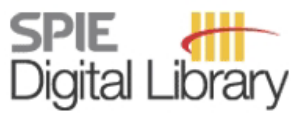

SPIEDigitalLibrary.org

Paper Numbering: Proceedings of SPIE follow an e-First publication model, with papers published first

online and then in print and on CD-ROM. Papers are published as they are submitted and meet publication criteria. A unique, consistent, permanent citation identifier (CID) number is assigned to each article at the time of the first publication. Utilization of CIDs allows articles to be fully citable as soon as they are published online, and connects the same identifier to all online, print, and electronic versions of the publication. SPIE uses a six-digit CID article numbering system in which:

- The first four digits correspond to the SPIE volume number.

- The last two digits indicate publication order within the volume using a Base 36 numbering system employing both numerals and letters. These two-number sets start with 00, 01, 02, 03, 04 , $05,06,07,08,09,0 A, 0 B \ldots$. 0Z, followed by 10-1Z, 20-2Z, etc.

The CID Number appears on each page of the manuscript. The complete citation is used on the first page, and an abbreviated version on subsequent pages. Numbers in the index correspond to the last two digits of the six-digit CID Number. 


\title{
Contents
}

\author{
xi Conference Committee \\ xiii Introduction
}

\section{GIS, GPS, AND RS IN AGRICULTURAL ENGINEERING}

876202 The research and development of water resources management information system based on ArcGIS [8762-2]

W. Cui, X. Gao, Y. Li, Z. Cui, Shandong Water Polytechnic (China)

876203 GIS-based weight of evidence modeling for cultivated land suitability mapping [8762-20] L. Lv, X. Zheng, China Univ. of Geosciences (China)

876204 Using RS and GIS techniques for soil and water resources protection in Lijiang city, China [8762-40]

Y. Song, Hangzhou Normal Univ. (China) and Zhejiang Provincial Key Lab. of Urban Wetlands and Regional Change (China); X. Song, Institute of Urban Environment (China); X. Guo, Yunnan Agricultural Univ. (China); W. Zhu, Hangzhou Normal Univ. (China) and Zhejiang Provincial Key Lab. of Urban Wetlands and Regional Change (China)

876205 Design and implementation of agricultural environment monitoring system based on GIS and SMS/GPRS [8762-50]

Y. Wu, Hebei Univ. of Economics and Business (China); M. Huang, Beijing Univ. of Civil Engineering and Architecture (China); X. Zhang, Hebei Univ. of Economics and Business (China)

876206 Sand dunes monitoring using remote sensing and GIS techniques for some sites in Iraq [8762-63]

A. M. Fadhil, Salahaddin Univ. (Iraq)

876207 Implementation of Ajax asynchronous communication technology and GWT-EXT client in agricultural macroscopic decision-making system WebGIS publish [8762-73]

L. Zhao, W. Wang, Hebei Luyuan Land Planning and Consulting Co., Ltd. (China); Y. Wu, Hebei Univ. of Economics and Business (China); M. Huang, Beijing Univ. of Civil Engineering and Architecture (China)

876208 Agricultural and urban land use change analysis in Changping County, Beijing, using remote sensing and GIS [8762-95]

M. Guo, X. Huang, H. Li, X. Li, Institute of Remote Sensing Applications (China); A. Ming, Beijing Municipal Research Institute of Environmental Protection (China) 
876209 Research on the application in disaster reduction for using cloud computing technology [8762-5]

L. Tao, Y. Fan, X. Wang, National Disaster Reduction Ctr. of China (China)

8762 0A Assessment of environmental health risk for drinking water sources [8762-30]

X. Hu, Z. XU, J. Wang, D. Zeng, Q. Han, South China Institute of Environmental Sciences (China)

8762 OB Design and implementation of fishery rescue data mart system [8762-31]

P. Jun, Wenzhou Univ. (China); H. Huang, Wenzhou Ocean and Fishery Service (China);

Y. Liu, Wenzhou Univ. (China)

$87620 \mathrm{C}$ Iterative learning control for nonlinearly parameterized systems with unknown control direction [8762-32]

Q. Yan, H. Wang, F. Yu, Zhejiang Water Conservancy and Hydropower College (China)

8762 OD Risk assessment of logistics outsourcing based on BP neural network [8762-37]

X. Liu, Z. Tian, Harbin Univ. of Commerce (China)

$8762 \mathrm{OE}$ Comparison and analysis of several non-rearranged dynamic multicast routing algorithms [8762-38]

Y. Dai, N. Li, Changchun Univ. (China)

8762 OF The components analysis of gross agricultural production in Hainan [8762-41]

Z. Liu, Y. Yang, Tropical Crops Genetic Resources Institute (China)

$87620 G$ The distribution proportion and production change of cucurbits and vegetables in Hainan [8762-42]

Z. Liu, Y. Yang, Tropical Crops Genetic Resources Institute (China)

$8762 \mathrm{OH}$ The ecological cultivation system construction of cucurbits and vegetables in Hainan [8762-43]

Z. Liu, Y. Yang, Tropical Crops Genetic Resources Institute (China)

8762 Ol Research on the degradation of tropical arable land soil: Part I. The soil acidification during the last two decades in Hainan, China [8762-45]

D. Wang, Z. Wei, Z. Qi, Tropical Crops Genetic Resources Institute (China)

8762 0J Research on the degradation of tropical arable land soil: Part II. The distribution of soil nutrients in eastern part of Hainan Island [8762-46]

D. Wang, Z. Wei, Z. Qi, Tropical Crops Genetic Resources Institute (China)

8762 OK Research on the degradation of tropical arable land soil: Part III. The distribution of Cd in western part of Hainan Island [8762-47]

D. Wang, Z. Wei, Z. Qi, Tropical Crops Genetic Resources Institute (China)

$8762 \mathrm{OL} \quad$ Background assessment and distribution of as in soil of Jiangxi Province, China [8762-51] M. Han, Hainan Univ. (China) and Tropical Crops Genetic Resources Institute (China);

D. Wang, Z. Wei, Tropical Crops Genetic Resources Institute (China); S. Tang, Hainan Univ. (China); Z. Qi, Tropical Crops Genetic Resources Institute (China) 
$87620 \mathrm{M}$ Study of a second order low pass filter based on hybrid SETMOS [8762-57]

L. Cai, Q. Kang, D. Y. Shi, Air Force Engineering Univ. (China)

8762 ON Risk degree evaluation on water and soil loss in central Hunan Province of red soil hilly region, China [8762-61]

Y. Zhang, Hunan Univ. (China) and South China Institute of Environmental Sciences

(China); Z. Li, Hunan Univ. (China); Z. Chen, South China Institute of Environmental Sciences

(China); X. Wang, Changsha Univ. of Science and Technology (China); X. Peng, South

China Institute of Environmental Sciences (China); M. Yuan, J. Huang, Hunan Univ. (China)

876200 Analysis of generic crop growth model for use in decision support systems for farmers [8762-64]

K. B. Vegesana, F. D. McKenzie, Old Dominion Univ. (United States)

8762 OP A simulation and experiment study on temperature of a forced ventilated greenhouse [8762-67]

Y. Zhao, Jiaxing Univ. (China); Q. Huang, J. Zhao, Jiaxing Univ. (China) and Jiangxi Univ. of

Science and Technology (China); D. Song, Jiaxing Univ. (China)

$87620 Q$ The application of data mining technology in the quality and security of agricultural products [8762-80]

H. Li, Y. LUo, Xiamen Univ. (China)

8762 OR Assessment of TRMM satellite precipitation data and its impacts on the water balance of the Heihe River basin [8762-84]

W. Qu, J. Lu, Z. Pang, China Institute of Water Resources and Hydropower Research

(China)

8762 OS Spatial pattern dynamics of quasi-circular plant community patches at Gudong oil field [8762-85]

Q. Liu, J. Dong, G. Liu, C. Huang, Institute of Geographical Sciences and Natural Resources Research (China)

8762 OT Genetic diversity of Phytophthora sojae isolates in Heilongjiang Province in China assessed by RAPD and EST-SSR [8762-96]

J. J. Wu, Heilongjiang Academy of Agricultural Sciences (China); P. F. Xu, Northeast Agricultural Univ. (China); L. J. Liu, J. S. Wang, W. G. Lin, Heilongjiang Academy of Agricultural Sciences (China); S. Z. Zhang, Northeast Agricultural Univ. (China); L. Wei, Heilongjiang Academy of Agricultural Sciences (China)

8762 OU Study on price transmission in China's broiler industry chain based on MCM [8762-100]

S. Xu, X. Dong, Z. Li, L. Cui, F. Kong, G. Li, H. Yu, Agricultural Information Institute (China), Key Lab. of Agri-Information Services Technology (China), and Key Lab. of Intelligent

Agricultural Early Warning Technology and System (China)

$8762 \mathrm{OV}$ Optimization of gastrodin and gastrodigenin extraction technology and effect of different harvest festivals on their contents [8762-103]

J. Zhang, D. Zhang, Hunan Univ. of Science and Technology (China); J. Qin, Shaanxi Univ. of Science and Technology (China) 
$8762 \mathrm{OW}$ The research of highway traffic accident management and pre-alarm system [8762-13] J. Xu, Jiangxi Transportation Consulting Co. (China); T. Zhang, J. Wan, J. Zhang, R. Wang, Research Institute of Highway, Ministry of Transportation (China)

$87620 X \quad$ Studies on antioxidant activity of teasaponins after hydrolyzed by enzyme [8762-15] J. Tian, S. Zhao, L. XU, X. Fei, X. Wang, Y. Wang, Dalian Polytechnic Univ. (China)

8762 OY An algorithm of fast index constructing and neighbor searching for 3D LiDAR data [8762-19] Y. Feng, Southwest Jiaotong Univ. (China) and Information Ctr. of Land and Resources Dept. (China); M. Cen, T. Zhang, Southwest Jiaotong Univ. (China)

$87620 Z$ Design of modular control system for grain dryers [8762-26]

G. He, Hefei Univ. of Technology (China); Y. Liu, Anhui Vocational and Technical College (China); Y. Zu, Hefei Univ. of Technology (China)

876210 Monitoring rice cropping systems using China environment satellite data in Poyang Lake region [8762-33]

P. Li, L. Jiang, Z. Feng, Institute of Geographical Sciences and Natural Resources Research (China)

876211 Calibration and correction of the device measuring magnetic gradient tensor [8762-44] Y. Huang, L. Wu, Harbin Engineering Univ. (China)

876212 Preparation of ferrous chelate of hairtail (Trichiurus haumela) protein hydrolysate (Fe(II)$\mathrm{HPH}$ ) and its antibacterial activity [8762-53]

H. Lin, B. Zhang, Zhejiang Ocean Univ. (China); T. Yu, Nanjing Agricultural Univ. (China); S. Deng, Zhejiang Ocean Univ. (China)

876213 Genetic structure and gene flow in the endangered aquatic economic crop Brasenia schreberi J. F. Gmel. (Nymphaeaceae) in China [8762-54] Y.-H. Dong, Jianghan Univ. (China); R. Wahiti Gituru, Jomo Kenyatta Univ. of Agriculture and Technology (Kenya)

876214 A novel compatible fingerprint algorithm based on multi-region alignment [8762-56] P. YU, The PLA Academy of Communication Command (China) and Naval Univ. of Engineering (China); G. Li, Chinese Navy Command (China); X. Li, South China Sea Fleet (China)

876215 Development for equipment of the milk macromolecules content detection [8762-62] G. Ding, Harbin Univ. of Science and Technology (China) and Heilongjiang Bayi Agriculture Univ. (China); W. Li, T. Shang, Y. Xi, Y. Gao, Heilongjiang Bayi Agriculture Univ. (China); Z. Zhou, Harbin Univ. of Science and Technology (China)

876216 Efficient algorithms for solution of interference cancellation and channel estimation for mobile OFDM system [8762-76]

T. Fan, Y. Wen, China Maritime Police Academy (China); C. Kadri, Chongqing Univ. (China) 
876217 Design and analysis of environmental information monitoring system based on ZigBee technology [8762-78]

K. Liu, B. Zhou, Q. Yang, Kunming Univ. of Science and Technology (China); H. Guo, China Agricultural Univ. (China); Z. Ge, Kunming Univ. of Science and Technology (China)

876218 Analysis of vegetation changes along the roadsides based on remote sensing [8762-81] Z. Li, X. Yao, J. Yu, W. Sun, Beijing Normal Univ. (China); H. Li, Beijing Normal Univ. (China) and China Academy of Transportation Sciences (China)

876219 Study on remote sensing monitoring of land use based on road net buffer [8762-82] H. Li, Beijing Normal Univ. (China) and Scientific Research Institute, Ministry of Transportation (China); L. Guan, J. Chen, Scientific Research Institute, Ministry of Transportation (China)

$87621 \mathrm{~A}$ The study and realization of satellite positioning algorithm in no light [8762-83] J. Li, J. Liu, Qingdao Agricultural Univ. (China)

8762 1B Greenhouse irrigation control system design based on ZigBee and fuzzy PID technology [8762-88]

B. Zhou, Q. Yang, K. Liu, Kunming Univ. of Science and Technology (China); P. Li, Southeast Univ. (China); J. Zhang, Q. Wang, Kunming Univ. of Science and Technology (China)

$87621 \mathrm{C}$ Measurement of surface albedo and its environmental effects over a temperate desert steppe [8762-93]

F. Yang, China Meteorological Administration (China); J. Zhou, Lanzhou Univ. (China)

8762 1D Researching on the process of remote sensing video imagery [8762-94]

H. Wang, X. Zheng, Y. Sun, Z. Jia, China Univ. of Geosciences (China); H. Wang, China Academy of Space Technology (China)

\section{SENSOR TECHNOLOGY IN AGRICULTURAL ENGINEERING}

8762 1E High resolution gas chromatography analysis of rice bran oil [8762-12]

F. Yu, Central South Univ. of Forestry and Technology (China) and Hunan Biological Electromechanical Polytechnic (China); Q. Lin, Central South Univ. of Forestry and Technology (China); X. Chen, Hunan Academy of Agricultural Sciences (China); X. Wei, Hunan Biological Electromechanical Polytechnic (China)

$8762 \mathrm{lF} \quad$ Purification of soyasaponin - $\beta$-galactosidase from Aspergillus sp.39 [8762-16] J. Tian, P. Zhao, L. Xu, X. Fei, Y. Wang, Dalian Polytechnic Univ. (China)

$87621 \mathrm{G} \quad$ Features of the photosynthetic tissue in the sheaths of rice (Oryza sativa L.) [8762-18] Z. W. Guo, Changsha Univ. of Science and Technology (China); Q. He, D. H. Feng, Hunan Hybrid Rice Research Ctr. (China)

$87621 \mathrm{H} \quad$ Corn leaf disease spot recognition comparative study of Bayesian classification and fuzzy pattern recognition [8762-21]

J. Zhu, B. Zhang, Heilongjiang Bayi Agriculture Univ. (China) 
$876211 \quad$ Analysis on water consumption relationship during the whole growing stage for winter wheat based on the remote sensing [8762-22]

Z. Pang, J. Fu, D. Cao, J. Lu, China Institute of Water Resources and Hydropower Research (China)

$87621 \mathrm{~J}$ A novel civilian granary temperature and humidity monitoring device based on C8051F020 [8762-48]

L. Meng, Military Transportation Univ. (China); Y. Li, Tianjin Polytechnic Univ. (China);

X. Meng, Tsinghua Univ. (China)

$87621 \mathrm{~K} \quad$ Simulation of fiber optic liquid level sensor demodulation system [8762-52]

C. Yi, Y. Luo, Z. Zhang, Guizhou Univ. (China)

$87621 \mathrm{~L} \quad$ Study on effect of soil temperature on FDR soil moisture sensor in frozen soil [8762-59] H. Tian, L. Ye, H. Chen, Henan Key Lab. of Agrometeorological Support and Applied Technique (China) and Henan Institute of Meteorological Science (China)

$87621 \mathrm{M}$ Design and test research of a new optical fiber F-P humidity sensing system for modern agriculture environmental monitor [8762-69]

N. Shan, The Chinese People's Armed Police Force (China); X. Liu, Northwestern

Polytechnical Univ. (China); S. Wang, The Chinese People's Armed Police Force (China)

$87621 \mathrm{~N}$ A novel equalization technique for high mobility OFDM system [8762-87]

T. Fan, Y. Wen, China Maritime Police Academy (China)

876210 Sterile measurement on the characteristics of chlorophyll fluorescence in plantlets in vitro preserved under low temperature condition [8762-105]

Y. Wu, Jiangsu Univ. (China) and Institute of Geochemistry (China); D. Xing, Jiangsu Univ. (China)

\section{OTHER RELATED INFORMATION TECHNOLOGY IN AGRICULTURAL ENGINEERING}

$87621 \mathrm{P} \quad$ Refraction properties of the electromagnetic wave in inhomogeneous plasma sphere [8762-23]

C. Wu, Y. Gong, W. Wu, S. He, H. Du, The PLA Univ. of Science and Technology (China)

$87621 Q \quad$ Analysis on electronic control unit of continuously variable transmission [8762-25]

S. Cao, Huaihai Institute of Technology (China)

8762 IR Research on area source electron gun in vacuum system [8762-34]

Y. Qiu, B. Chang, F. Shi, Y. Qian, R. Fu, Nanjing Univ. of Science and Technology (China)

8762 is Locally applied simvastatin improves fracture healing at late period in osteoporotic rat [8762-35]

F. Tian, Hebei United Univ. (China); L. Zhang, Y. Kang, J. Zhang, J. Ao, Affiliated Hospital of Hebei United Univ. (China); F. Yang, Hebei United Univ. (China)

8762 1T Insulation grapes cold winter effect [8762-36]

S. Guo, M. Li, Xinjiang Academy of Agricultural and Reclamation Science (China); L. Ying, Fifth Agricultural Division of XPCC (China) 
$87621 \mathrm{U}$ Occlusion processing using particle filter and background subtraction algorithms [8762-49] T. Guo, J. Rong, K. Lu, Univ. of Electronic Science and Technology of China (China);

$X$. Zhong, Southwest Jiaotong Univ. (China)

$87621 \mathrm{~V}$ Research on the ELID-ultrasound dressing technology based on multi-field coupling theory [8762-70]

J. Kuai, Henan Polytechnic Univ. (China)

$87621 \mathrm{~W}$ Public-key management in mobile ad hoc networks [8762-90]

H. Lin, A. Jiang, Nanjing Forestry Univ. (China); D. Bai, Nanjing Agricultural Univ. (China);

Y. Liu, Nanjing Forestry Univ. (China)

$87621 \mathrm{X} \quad$ Public traffic transfer algorithm design [8762-92]

K.-Y. Yin, L. Jin, B. Qian, Nanjing Research Institute of Electronics Technology (China);

K. Fang, China Electronics Technology Group Corp. (China)

$87621 Y \quad$ Research on gait-based human identification [8762-97]

Y. Li, Xinyang Agricultural College (China)

876212 Automatic extraction of relationships between concepts based on ontology [8762-101] Y. Yuan, J. Du, Y. Yang, J. Zhou, P. He, S. Cao, Beijing Univ. of Posts and Telecommunications (China)

876220 Variable rate modulation on FPGA [8762-102]

H. Zhai, X. Man, E. Zhang, National Univ. of Defense Technology (China)

$876221 \quad$ Design of software engineering teaching website [8762-9]

Y. Li, X. Liu, G Zhang, X. Liu, Z. Gao, Hebei Normal Univ. of Science and Technology (China)

Author Index 
Proc. of SPIE Vol. $8762876201-10$

Downloaded From: https://www.spiedigitallibrary.org/conference-proceedings-of-spie on 25 Apr 2023 Terms of Use: https://www.spiedigitallibrary.org/terms-of-use 


\section{Conference Committee}

Honorary Conference Chairs

Chin-Chen Chang, IEEE Fellow, Feng Chia University (Taiwan)

Jun Wang, IEEE Fellow, Faculty of Engineering, The Chinese University of Hong Kong (Hong Kong)

Garry Lee, Information Engineering Research Institute (United States)

Keynote Speakers

Jun Wang, IEEE Fellow, Faculty of Engineering, The Chinese University of Hong Kong (Hong Kong)

Wu Yijin, Huazhong Normal University (China)

\section{Conference Chairs}

Honghua Tan, Wuhan Institute of Technology (China)

Wu Yijin, Huazhong Normal University (China)

Program Committee

Jian Li, Hubei Normal University (China)

Qi Luo, Wuhan Institute of Technology (China)

Zhu Min, Nanchang University (China)

Min-Yi Shih, IEEE Photonics Society Member, Technical Committees on Optoelectronic Packaging, Manufacturing \& Reliability(United States)

David Plant, IEEE Photonics Society Member, Technical Committees on Optoelectronic Packaging Optical Interconnects \& Processing Systems (United States)

Ho-Chiao Chuang, National Taipei University of Technology (Taiwan)

Yiyi Zhouzhou, Azerbaijan State Oil Academy (Azerbaijan)

David Wang, IEEE Nanotechnology Council Cambodia Chapter Chair Cambodia (Cambodia)

Srinivas Aluru, ACM NUS Singapore Chapter (Singapore)

Tatsuya Akutsu, ACM NUS Singapore Chapter (Singapore)

Khine Soe Thaung, Maldives College of Higher Education (Maldives) 
Session Chairs

Session on Image Processing in Agricultural Engineering

Wu Yijin, Huazhong Normal University (China)

Session 1: Image Processing in Agricultural Engineering

Honghua Tan, Wuhan Institute of Technology (China)

Session 2: Photonics in Agricultural Engineering

Wu Yijin, Huazhong Normal University (China)

Session 3: GIS, GPS, RS in Agricultural Engineering

Wu Yijin, Huazhong Normal University (China)

Session 4: Wireless and Optical Communications in Agricultural

Engineering

Honghua Tan, Wuhan Institute of Technology (China)

Session 5: Agricultural Decision Support and Simulation System

Zhu Min, Nanchang University (China)

Session 6: Intelligent Monitoring and Control/ICT Applications in Rural Area

Jun Wang, IEEE Fellow, Faculty of Engineering, The Chinese University of Hong Kong (Hong Kong)

Session 7: Sensor Technology in Agricultural Engineering

Qi Luo,Wuhan Institute of Technology(China)

Session 8: Other Related Information Technology in Agricultural Engineering

Jun Wang, IEEE Fellow, Faculty of Engineering, The Chinese University of Hong Kong (Hong Kong) 


\section{Introduction}

The 2013 3rd International Conference on Photonics and Image in Agriculture Engineering (PIAGENG 2013) was held 27-28 January 2013 in Sanya, China.

PIAGENG 2013 is the most comprehensive conference focused on the various aspects of advances in photonics and image in agriculture engineering. The goal of this conference is to bring together the researchers from academia and industry, as well as practitioners to share ideas, problems, and solutions relating to the multifaceted aspects of photonics and image in agriculture engineering.

Wireless communication is the transfer of information between two or more points that are not connected by an electrical conductor. The most common wireless technologies use electromagnetic wireless telecommunications, such as radio. With radio waves, distances can be short, such as a few meters for television remote control, or as far as thousands or even millions of kilometers for deepspace radio communications. It encompasses various types of fixed, mobile, and portable applications, including two-way radios, cellular telephones, personal digital assistants (PDAs), and wireless networking. Other examples of applications of radio wireless technology include GPS units, garage door openers, wireless computer mice, keyboards and headsets, headphones, radio receivers, satellite television, broadcast television and cordless telephones. Less common methods of achieving wireless communications include the use of light, sound, magnetic, or electric fields.

Optical communication is any form of telecommunication that uses light as the transmission medium. It can be performed visually or it can be undertaken in an electronic form. Early forms of visual optical communications date back several millenniums. An optical communication system uses a transmitter, which encodes a message into an optical signal, a channel, which carries the signal to its destination, and a receiver, which reproduces the message from the received optical signal. The earliest electrical form of optical communication was the photo phone, invented in 1880. Free space optical communication has been deployed in space, while terrestrial forms of optical communication are limited by geography, weather and the availability of light.

I wish to express my appreciation to all the members of organizing committee, academic committee and program committee as well as the referees, staff, and volunteers for their tremendous efforts and dedication. Without their hard work and excellent jobs, it was impossible to lead the success of this book.

Honghua Tan 
Proc. of SPIE Vol. $8762876201-14$

Downloaded From: https://www.spiedigitallibrary.org/conference-proceedings-of-spie on 25 Apr 2023 Terms of Use: https://www.spiedigitallibrary.org/terms-of-use 